\title{
Determining the cadastral-tax areas for the real estate premises based on the model of qualitative and quantitative
}

\author{
Elżbieta Jasińska ${ }^{1}$, Edward Preweda $^{2}$ \\ ${ }^{I}$ Department of Geomatics, Faculty of Mining Surveying and Environmental Engineering AGH University of Science \\ and Technology in Kraków \\ ${ }^{2}$ Department of Geomatics, Faculty of Mining Surveying and Environmental Engineering AGH University of Science \\ and Technology in Kraków
}

E-mail: ${ }^{1}$ elzbieta.jasinska@agh.edu.pl ${ }^{2}$ edward.preweda@agh.edu.pl

\begin{abstract}
The approach to the cadastral value of the property is an indicator of the development of the real estate market, and therefore there are still divisions between countries preferring addictive this value from the surface and from values. The article comments on regulatory presented in selected European Union countries and presents original solution for the determination and correction of the cadastral value of the property, which is the basis to determine the property tax. About the tax character of this value, the fact that the introduction of social concern.

Based on Poland, more than twenty years there has been discussion on this subject, but without regulation, there is only a discuss about the concepts of the system. The first attempts spatial analysis in order to determine the cadastral-tax areas have not yielded sufficient results, which is why the authors decided to present original solution resulting from the combination of statistical methods inclusive quantitative traits (facet surface) and qualitative characteristics (standard flat) with the characteristics of spatial (location, neighbourhood), in to determine the cadastral value of the property to eventually create the zones in cadastral-tax-zones. As an example, the property from the city Bochnia were used. The paper sought optimal zoning, to minimize variations and create homogeneous collections, which are enclosed areas, so that the weightings were small. To do this, the property housing was selected, as constituting the highest percentage of items on the market.
\end{abstract}

Keywords: Cadastral tax, land use, local fees, regression, regression tree, real estate valuation

Conference topic: Technologies of Geodesy and Cadastre

\section{Introduction}

In Poland, for several years there has been discussion about the replacement of surface property taxes a tax register. However, there is here a basic tool which is a unified system that contains complete information about the property, especially their values, i.e. cadastre. Necessary in a mass real estate valuation elements are tables and taxations maps. The aim of this study is to build the taxation map for the city Bochnia. This map will primarily assist in determining future rate cadastral tax in the city by local authorities, and at the same may be informative for residents or parties interested in buying real estate in the city. The proposed solution is a project copyright not one certainly legitimate, but nevertheless facilitates the process of general valuation. An attempt to automate the valuation for tax purposes and to update the forms of taxation maps the needs of the growing real estate market premises.

Before taking any step on the real estate market, it is necessary to familiarize with the specificity of this market (Jasińska E., 2014). One of its most important features is the distribution of property value. Currently, data of this type are found mainly in the Register of Prices and values, and are accessible only to authorized persons and for a fee. A secondary objective of this study is to disseminate information about the estimated value of the property at an affordable form of maps and a clear algorithm used for its calculation.

\section{Taxation}

Taxation in Poland controversial topic, especially for residents of the centres of large cities, who received Sale inherited or bought it at a bargain price of housing, and their current incomes are not high (Jędrysiak M., 2014). The current tax system is used, however paradoxical solutions as the sole determinant of the amount paid property tax is

(C) 2017 Elżbieta Jasińska, Edward Preweda. Published by VGTU Press. This is an open-access article distributed under the terms of the Creative Commons Attribution (CC BY-NC 4.0) License, which permits unrestricted use, distribution, and reproduction in any medium, provided the original author and source are credited. 
its surface. This means that the owner of the property located on the outskirts of Krakow pay the same contribution as the owner of an apartment in the city canter, despite the significant difference in their values (Bryndziak Sz., 2011). In this case, it seems necessary to reform the taxation of real estate in Poland (Etel L., 1999). When entering the cadastral tax probably will be a lot of problems. The biggest of them may turn out to be the high cost of carrying out the operation. Per some, they could even reach 2 billion PLN (Jędrysiak, 2014). It is estimated that the most expensive, despite the methods of mass appraisal, will be the introduction and continuous updating of the system, which would be calculated on the value of the real estate cadastre.

To reduce costs and shorten time-to-cadastral tax on the market there are already many solutions that will greatly facilitate its introduction. Professor Andrzej Hopfer (Hopfer A., 2008) describes a method of mass valuation of properties and attributes that should be considered in the valuation of the cadastral value, showing that the characteristics that distinguish it from the market value. On the other hand, (Sawiłow E.,2008) on the example of the three registration precincts located in Wroclaw presents a methodology of determining the cadastral value, which is based on a Registry Prices and values of real estate.

European countries represent a variety of solutions in the field of real estate taxation, which are similar. The diversity of systems of taxation of real estate due to the lack of uniform regulations in this field within the European Union and the absence of international standards for the construction of these systems. All systems existing in Europe can be summarized in two general groups:

1. valuable systems, where the tax base is the value of the property obtained by the mass valuation

2. systems for surface based on the surface of taxable property.

In the case of ad valorem taxation of all data necessary to determine the amount of tax included in the real estate cadastre, and systems of surface basic information including geodetic and cartographic records. When selected country a complete lack of cadastre of real estate, these records are the primary source of data on real estate for the payers and the authorities of the state treasury (Mika M., Len P. 2016.).

Among the EU member states is most popular cadastral system, which is based on the capital value of the property or rental value. Because all the information about taxpayers and taxable properties are in the cadastre, determination and collection of taxes does not make difficulties. Currently, European countries operate cadastre fiscal and legal. Fiscal Cadastre contains data on the taxpayer, the value of the property and the income they generate. These are the data needed most of all the tasks in the field of taxation, but can be used for other purposes. Cadastral law, in turn, deals with the legal aspects of real estate, and its main purpose is the registration and protection of property rights and the burden of property. As a rule, it is associated with the system of land registers, and sometimes it replaces, and it may also be a source of tax information. The creation of the legal cadastre is relatively difficult and costly for the time, because it requires settlement of legal relations to real estate and determine its exact boundaries (Hanus P, Jasińska E. Preweda E. 2014).

The surface is used only in the Czech Republic, Slovakia, Bulgaria and Poland, while Hungary and Romania applied intermediate solutions that combine elements of both systems.

The differences between the described systems are most evident in the size of the proceeds to the Treasury. At their height in the system register does not affect inflation, as it is in the system surface. On the other hand, the physical size (area) despite rising inflation remain unchanged, which does not change the very basis of taxation. This happens only in a system of value when property prices are rising.

In European countries, a plurality of types of securities systems which differ from each other in terms of subjective and objective. The entity, otherwise the taxpayer, or the property owner or user. In the case of this dimension, there are two possibilities:

- a tax covering a wide scope (many types of real estate)

- some taxes, each relating to a different type of real estate.

The first solution is more popular in Europe and is flavored by most countries. Few, however, have opted for the division of taxes, depending on the type of property. These are countries such as the UK, France and Denmark. In the UK, the property is divided into two types: residential (subject to tax Council Tax), and for other purposes than residential (tax Non-Domestic Rate). Likewise, the matter is in France. There stands a residential property, which is discharged from the tax habitaton, built-up, subject to excise taxefonciere sur lespropertiesbaties and undeveloped - tax taxefonciere sur lesproprieties non baties.

Another aspect of the differentiation system is valuable way to assess real estate value and the frequency of its revision. There are various ways of estimating real estate used in determining the amount of tax, which are:

- Taxation widespread, performed with the income or comparator. Recognition of income involves determining the income derived from the property and small it by the sum of the costs incurred in maintaining the property and its value. The comparative approach, however, is based on the value of real estate representative and later correcting this value, depending on the circumstances that distinguish these two properties, which are eg. Surface area, the technical condition of the area and the time factor,

- Auto- taxation - when the taxpayer has declared the value of its real estate, which belongs to the range previously announced by the tax authorities, 
- method of accounting books, in which the taxable amount is the carrying book value of the property, usually determined by the company, possessing the property.

The most commonly used method among the EU member states is a common taxation property. For her to carry out the responsibility of the selected bodies of government or local government.

Developed countries such as the USA, Canada, Australia and Western European countries, tax criticize surface, replacing many of its disadvantages (Dzikowska T. [et al.]. 2015):

- system is not fair for the public, because the owners of luxury properties are charged as much as the owners of the property of low value and usefulness, the system does not consider the economic capacity of the taxpayer burden more entrepreneurs who are the owners of the property used for commercial purposes,

- tends to hasty purchases of cheap residential and agricultural, which block long their optimal development and adversely affect the economic processes in the region,

- motivates to make effective use of the property with high potential for profit, so that the most valuable and best located land, giving many opportunities do not always produce similar benefits.

- the low credibility of the records of buildings and premises, as well as the lack of records of the building, resulting in a lack of taxation objects not included in the abovementioned records,

- low agricultural tax,

- relying on the classification of the land, so that land designated for agricultural production, and not covered by it, in fact, are taxed favourably,

- no account of the cost of raising the standard of real estate, for example. Improve its technical infrastructure.

Following the example of western neighbours, the Polish authorities in the early 90s began to make plans for the introduction of the cadastral system. Resumption of work was just then most likely due to reactivation of local government. The authorities have sought to reform the property tax system surface system ad valorem. It was also planned establishment of the cadastre; whose main aim was to collect data on the properties and their owners for tax purposes. The records would be helpful not only to the tax authorities, but also the authorities managing the technical infrastructure, spatial planning, land management and national statistics.

Despite the started reforms and noticeable inadequacy of the Polish system of real estate taxation to the solutions used in other European Union countries, the exact date of the introduction of a cadastral tax was never agreed upon. Its implementation, however, seems to be a foregone conclusion. It will bring several results, both positive and negative for both, in this case, the opposition parties, namely local authorities and citizens.

The most frequently cited in the literature of the advantages of the introduction of ad valorem taxation is (Piekut J. 2014):

- fairness of taxation - the owners of the property well-off, with numerous values, will be required to pay higher premiums than those with property located in the inferior or undeveloped land,

- redistribution of wealth in society - in most cases persons with high assets are more expensive real estate and, conversely, the less wealthy are the owners of less valuable property,

- better allocation of resources - targeted property owners attractively-off will be those of the measures allowing to maintain the property in due to the location condition,

- higher revenues for the municipal budget - update records will include tax objects that have not been so far in the disclosed, and the part of the property,

- increased traffic on the real estate market - property owners of high-value, which do not provide adequate revenue will resell them to get rid of the burden of the tax, so that real estate prices will fall and increase their availability in the market,

- Better use of space - an increase in the tax burden on the property of high value will positively affect the structure of the buildings of the cities, and especially their centres, within which are the most expensive real estate. Legacy of socialism is wasteful allocation of unprofitable facilities in areas of high economic potential. Examples of such objects are allotments, military areas or stations, located in attractive locations. Thus, the housing expands on the outskirts of cities, which complicates the lives of the inhabitants and increases maintenance costs. The increase in the tax burden in valuable locations would give impetus to carry inefficient institutions and productive investment in the urban space.

\section{Empirical example}

Computing work based on the Register of Prices and Values Bochnia in the format ".xls", which included information about the properties built residential and residential premises. Due to the complex nature and the lack of detailed information on the property built an attempt to create a reliable model was not possible. Therefore, from 4115 transactions for analysis were selected 99 transactions involving only residential premises, which are more frequently traded in Bochnia. In the first step of the analysis they were eliminated transactions, in which:

- missed recording surface, the address, the transaction price, number of rooms or floor, 
- appeared logic errors (e.g.: price for the property housing portion of the surface of $56,59 \mathrm{~m}^{2}$ amounted to 289.827 PLN 1 for $1,172.54 \mathrm{~m}^{2}$ ), and the lack of certainty as to the interpretation of the writing, the clarity of the provisions of the other, caused the decision to remove such records

- Sales were tender, left only sales on the open market.

Of the remaining 435 transactions were selected in terms of the position of those related to properties spread evenly throughout the city Bochnia (43 suites, yellow). After separation tax zones, it turned out that there are not enough that the results were satisfactory for each zone, so inside the zones searched additional premises (separate numbering: 50-99, orange). The properties were located through addresses in Google Earth, where were written the approximate geographical coordinates for later transfer points to the ArcMap program. Their locations are shown in Figure 1.

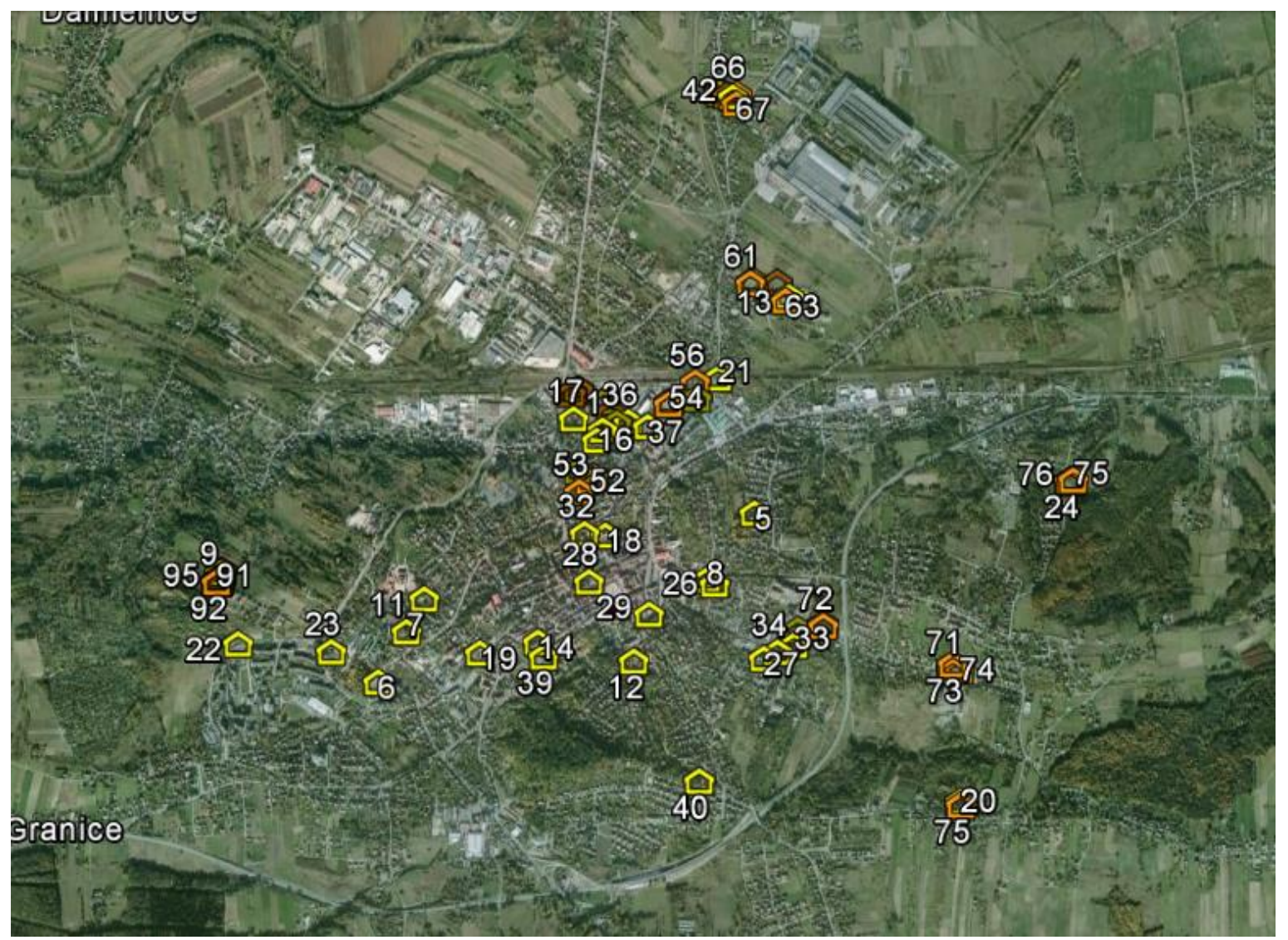

Fig. 1. Distribution of residential premises in the city Bochnia. Source: Own Study

To carry out the analysis of the real estate market in Bochnia was elected Statistica and available in the multiple regression method. The aim of this method is to create an algorithm that clarifies the influence of independent variables (explanatory), which examined the attributes for the dependent variable (explanatory) - cadastral value of the property. The regression coefficients describe the degree of relationship between the single independent variable and the dependent variable and its impact on the prediction of dependent variable. Where the coefficient is positive, with an increase in its predictive value increases, and vice versa, if negative - decreases. The described relationship can be represented by the formula:

$$
\mathrm{W}_{\mathrm{k}}=\mathrm{a}+\sum_{\mathrm{i}=1}^{\mathrm{n}} \mathrm{X}_{\mathrm{n}} \times \mathrm{b}_{\mathrm{n}}
$$

where:

$\mathrm{W}_{\mathrm{k}}$ - the cadastral value of the property,

$\mathrm{a}$ - the word free,

$\mathrm{X}_{\mathrm{n}}-\mathrm{n}$-th attribute property,

$b_{n}$ - regression coefficient for the $n$-th explanatory variable,

$\mathrm{n}$ - number attribute. 

tive and quantitative

It is not possible to appoint the ideal prediction model based on the characteristics of the property, which stipulates the paid price. Predicted values is always greater or lesser extent different from the actual values. The difference between them is called the residual value. Prediction is more precise the smaller the variance of residuals in relation to the total variation. This ratio is 0 when the variables are closely interdependent, and 1 if there is no relationship between the explanatory variables and the dependent variable. Usually its value is somewhere in the middle of this range, and informs you how much of the variability of the examined phenomenon is not caused regression. The key here is the coefficient of determination. It measures the degree of justification variability of the dependent variable regression model and reflects the quality of prediction. The closer it is to 1, the model more precise (Preweda E.,2013).

To create a regression model was generated file containing the attributes of all properties which are the subject of analysis. Such as:

- $\mathrm{X}_{1}$ - the area of real estate $\left(\mathrm{m}^{2}\right)$

- $\mathrm{X}_{2}$ - storey: from 1 to 6 ,

- $\mathrm{X}_{3}$ - number of rooms: from 1 to 5 ,

- $\mathrm{X}_{4}$ - surroundings: negative (1), preferred (2) or very favourable (3)

- $\mathrm{X}_{5}$ - transport access: negative (1), poor (2), beneficial (3), or very beneficial (4)

- $\mathrm{X}_{6}$ - standard: low (1), medium (2), high (3) or very high (4).

Features: 'face transactions', 'floor' and 'number of rooms' came from RCiW, while other attributes ('transport access', 'surroundings' and 'standard') were classified during the interview field. The variable ('transport access" was evaluated based on the distance of the property from public roads with different traffic. Unfavourable for the environment was considered a built area of industrial buildings, for residential purposes hostile to the infrastructure. The degree of 'beneficial' awarded for real estate situated in the residential areas, and the 'very beneficial' objects lying surrounded by parks, forests and open space. Variable standard depended on the condition and level of comfort of the building and premises.

To show the validity of the division of the city into zones made a prediction model for the whole of its territory. In this case, the adjusted coefficient of determination $\mathrm{R}^{2}$ is 0.36 . Its height indicates a very low quality prediction, and thus the need for zoning, in precincts where the property has more in common. That is why the classification tree was created (regression task) - to enter the characteristics of a qualitative nature (Jasińska E., 2012). Example of such a tree is given below (see Fig 2).

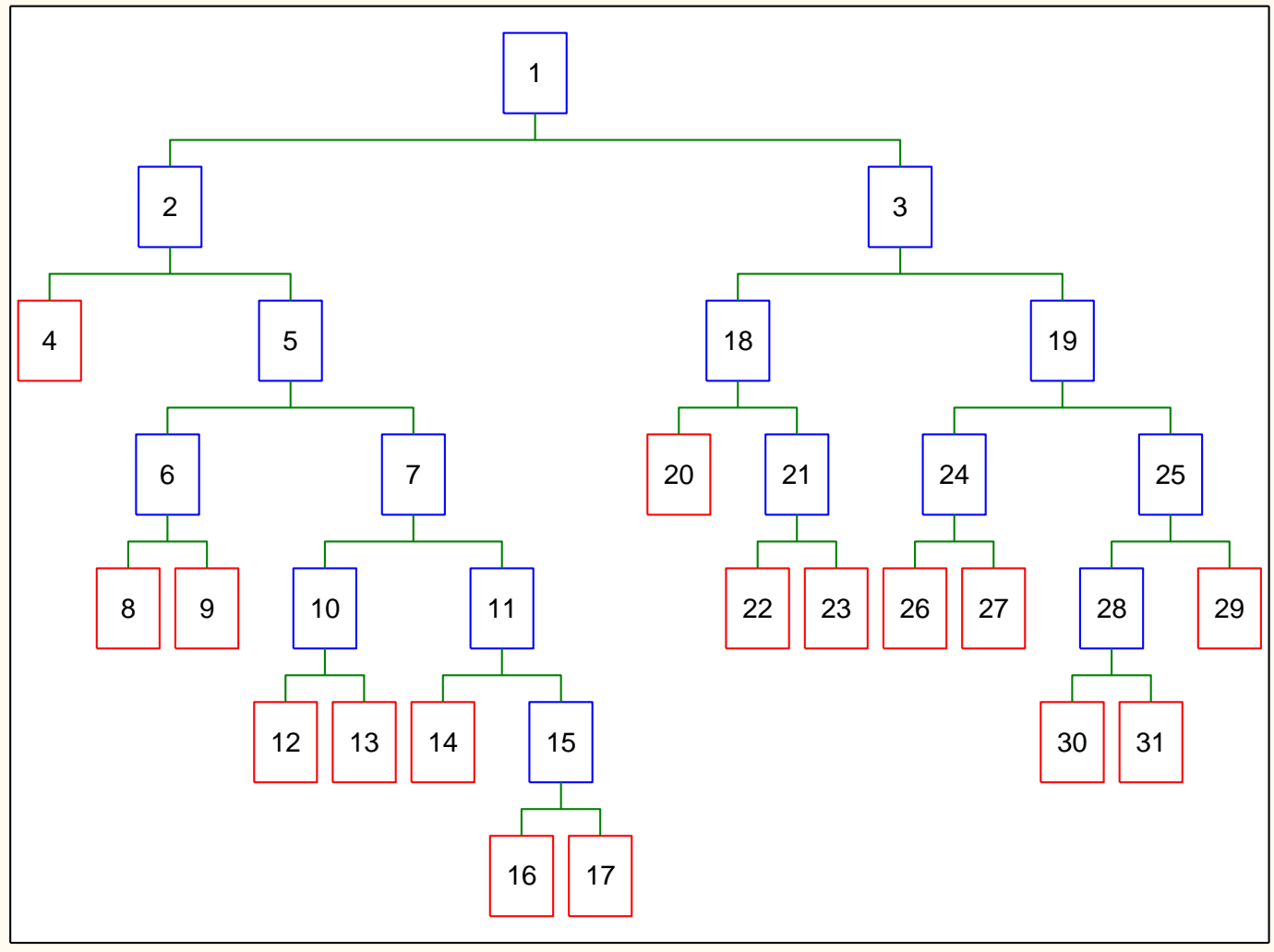

Fig. 2. Regression tree diagram. Source; Own Study 
Inclusion in the analysis of the predictor, which was the address of the property greatly influenced the ranking of validity of attributes- it has just the position of the Street (address), has the most impact of real estate prices (see Fig. $3)$.

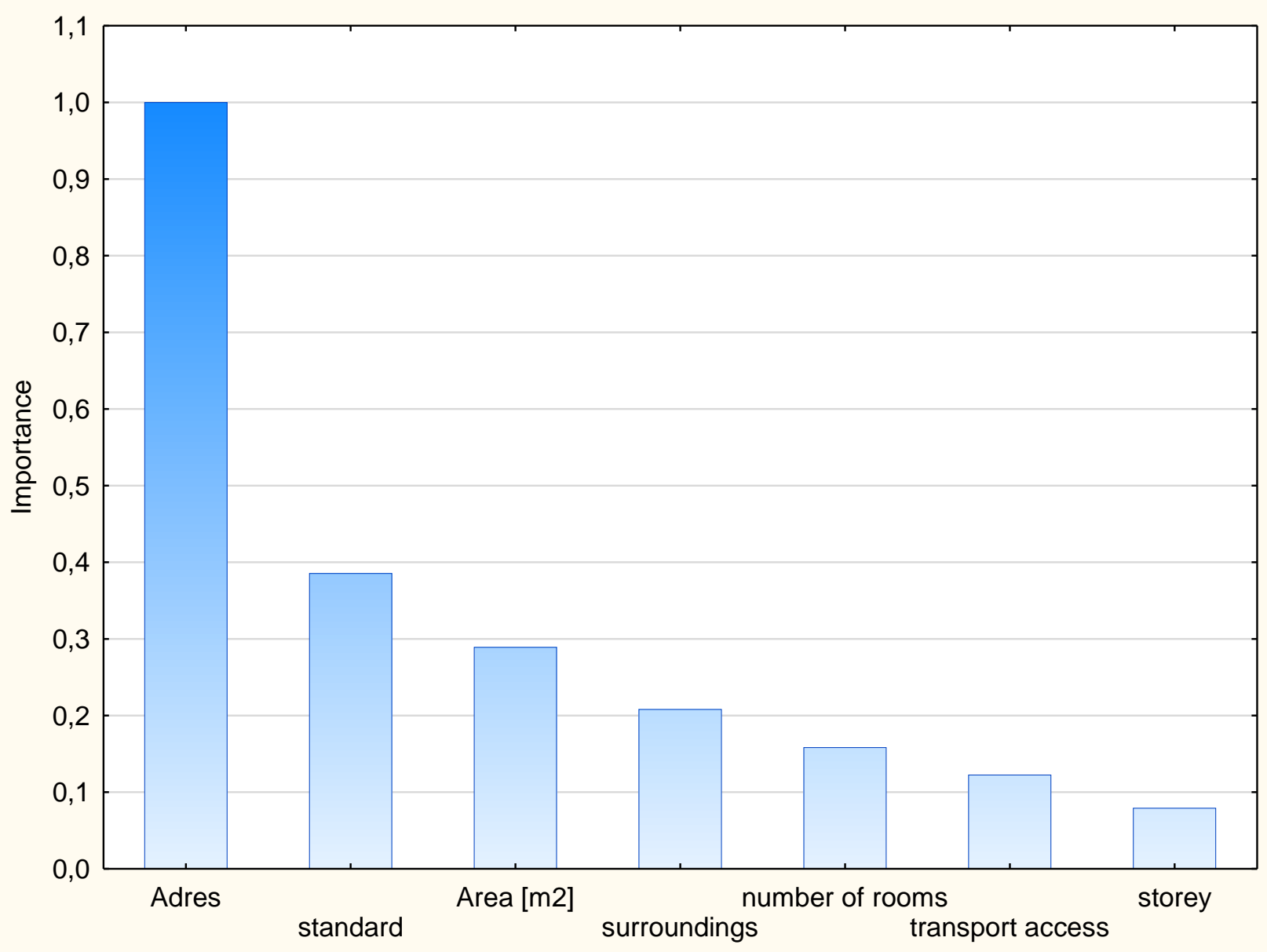

Fig. 3. Chart validity attributes. Source: Own study

The territory of the city was divided into taxations zones using attribute-based approach, in which the study area is divided into zones of homogeneous in terms of agreed criteria. The boundaries have been adjusted based on the location of roads, railway lines, borders and settlements built uniform. The separation zones were under the assumption that they should focus their properties with similar characteristics, which will have a similar unit value.

Steps mapping zones within the attribute-based approach are (Źróbek S., Cellmer R., Kuryj J, Janowski A. 2004):

1) Determination of the number of zones and criteria for identifying areas.

2) Identification and generalization borders.

3) The selection of representative transactions in the zones.

4) Determination of correlation coefficients to automate the calculation of cadastral value of the property in designated areas.

Taxations designated zones are shown in Figure 4. It also appears on the spatial distribution of the estate premises, but by a large reduction not all of them are visible. 


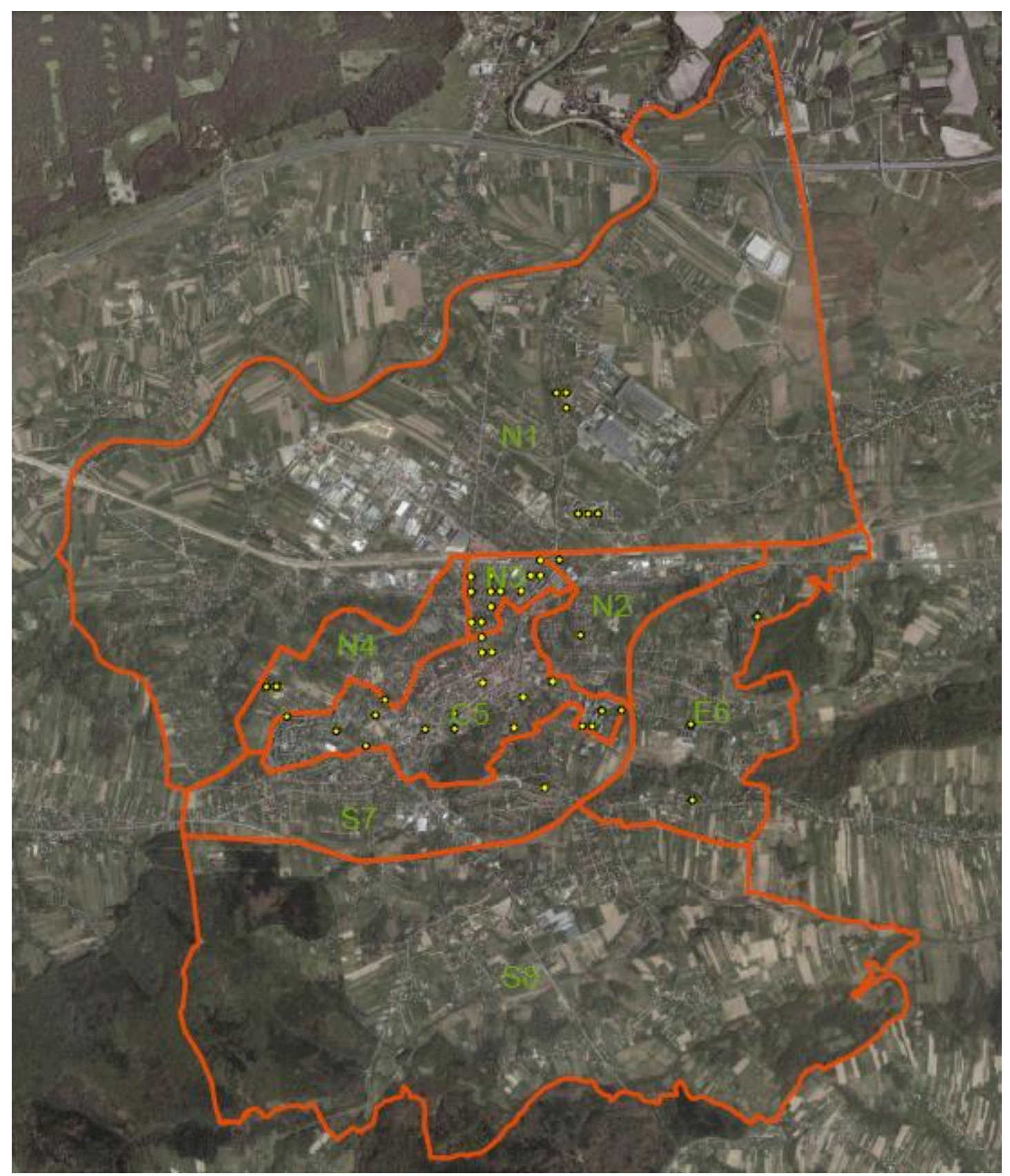

Fig. 4. Taxation zone in the city Bochnia. Source: Own Study

In the case of zone N1 is 'intercept' and 'number of rooms'. Adjusted coefficient of determination R2 is 0.85 , which means that $85 \%$ of the volatility of the value of the property is justified due contained in the valuation of attributes. Verification of statistical hypothesis about the importance of the structural parameters of the model showed that the parameters relevant to the significance level 0.05 are parameters:

- $\mathrm{X}_{1}$ - the area of real estate,

- $\mathrm{X}_{2}$ - storey,

- $\mathrm{X}_{3}$ - number of rooms,

- $\mathrm{X}_{4}$ - surroundings,

- $\mathrm{X}_{5}$ - transport access,

- $\mathrm{X}_{6}-$ standard.

In the case of zone N3 real estate did not differ in terms of the environment, because this feature has not been considered in the calculations. Rejected observations number 2, 30, 31, 36 and 52 as too turned out. Thus, significant remaining parameters 'transport access' and 'standard'. Adjusted coefficient of determination R2 is 0.83 , which is a rather high-quality prediction.

The transactions recorded in the zone N4 come exclusively from a single building, because in the zone there are no other real estate housing. The analysis was carried out for scientific purposes, to see what attributes are important 
in the case of real estate sold by the developer. They passed at the same attributes: 'standard', 'surroundings' and 'transport access', because they were equal. Other attributes ('intercept', 'area', 'storey' and 'number of rooms') proved to be significant. This is confirmed by the fact that real estate values were determined by an algorithm based inter alia on the selected attributes. The correctness of the analysis also confirms the high adjusted coefficient of determination $\mathrm{R} 2$, which is 0.93 .

\section{Conclusions}

Legal regulations about mass valuation and cadastral tax seem to be in today's realities to be a bit outdated. Preparations for the introduction of an ad valorem stalled and cannot be seen from the authorities any efforts to resume activities in this field. In the current legislation, there is no concept of tax dwellings maps, and they are in many Polish cities most frequent traded. It therefore seems improper to not create such documents, and for this reason was carried out the analysis in this study. The inclusion of qualitative characteristics is necessary to raise the accuracy of the generated models, especially in the case of heterogeneous data. In the present case, perfectly proven classification trees (for the regression task), which allowed the separation of taxations zones, and then to develop a linear regression model in each zone. All developed models allow for automatic calculation of cadastral values for any, prepared per the present scheme, a database of real estate. The proposed solution is the only legitimate way to calculate the cadastral value of the property, no less, however, it facilitates the process of general valuation.

\section{Funding}

This work was carried out within the statutory studies of the AGH University of Science and Technology, Faculty of Mining Surveying and Environmental Engineering, Department of Geomatics No. 11.11.150.006.

\section{References}

Bryndziak Sz., 2011: Czy podatek od wartości nieruchomości jest szansą na zwiększenie dochodów samorządu terytorialnego? Studia Prawno-Ekonomiczne Nr 84, s. 39-52, Łódź.

Dzikowska T., Jasińska E., Konieczna J., Kucharska-Stasiak E., Łupiński W., Trystuła A.2015. Wprowadzenie do katastru nieruchomości. Warszawa : Texter, 2016. - e-ISBN: 978-83-7790-544-9,

Etel L. (red.), 2003: Europejskie systemy opodatkowania nieruchomości. Biuletyn Biura Studiów i Ekspertyz Kancelarii Sejmu, Warszawa.

Hanus, P., Jasińska, E., Preweda, E. 2014. Analysis of the accuracy of determining the coordinates property borders. International Conference on Environmental Engineering. 9th International Conference on Environmental Engineering (ICEE), Vilnius, LITHUANIA, MAY 22-23, 2014. DOI: 10.3846/enviro.2014.191.

Hopfer A., 2008: Metody masowej wyceny. Wydział Prawa i Administracji UW, http://www2.wpia.uw.edu.pl/files//podyplomowe/rzeczoznawstwo/metody_wyceny_masowej_Hopfer.pdf

Jasińska E. 2012. Wybrane metody statystyczne w analizie rynku nieruchomości (Chosen Statistical Method In Real Estate Market Analysis) - monografia. Poland, 2012, DOI: 10.13140/RG.2.1.2686.9204/1

Jasińska E. 2014. Real Estate Due Diligence On the Example of the Polish Market, 14th SGEM GeoConference on Informatics, Geoinformatics and Remote Sensing 2. SGEM2014 Conference Proceedings, June 19-25, 2014, Vol. 2 , Bulgaria, 2014, http://dx.doi.org/10.5593/sgem2014/b22/s9.053

Jędrysiak M., 2014: Doktrynalne koncepcje reformy systemu opodatkowania lokalnego w Polsce. Uniwersytet Ekonomiczny we Wrocławiu, http://apcz.pl/czasopisma/index.php/SeI/article/download/7743/7041

Mika M., Len P. 2016. Analysis of the faulty spatial structure of land in the context of assessing the quality of cadastral data in poland. 16th International Multidisciplinary Scientific GeoConference SGEM 2016, www.sgem.org, SGEM2016 Conference Proceedings, ISBN 978-619-7105-59-9 / ISSN 1314-2704, June 28 - July 6, 2016, Book 2 Vol. 2. Pages 91-100. DOI: 10.5593/SGEM2016/B22/S09.013.

J. Piekut, Wady i zalety wprowadzenia podatku katastralnego [w:] Kwartalnik Naukowy Uczelni Vistula Nr 3/2014, Warszawa 2014, s. 87-89.

Preweda, E. 2013. Rachunek wyrównawczy $\Rightarrow$ modele statystyczne [Adjustment computations $\Rightarrow$ statistical models]. Progres, Kraków 2013 (2013): 1-387.

Sawiłow E., 2008: Metodyka ustalania wartości katastralnej. Studia i materiały Towarzystwa Naukowego Nieruchomości Volume $16 \mathrm{Nr} 3$, s.115-123, Olsztyn.

Źróbek S., Cellmer R., Kuryj J, Janowski A. 2004 Mapy przeciętnych wartości gruntów - narzędzie pomocnicze w powszechnej taksacji nieruchomości, http://www.i-net.pl/publikacje/cellmer-janowski-kuryj-zrobek-2004.pdf, p. 2. 